\title{
Orient and orientalizing in early celtic art
}

\begin{abstract}
N. K. SANDARS
Some of our readers will have visited the admirable exhibition of early celtic art in Edinburgh last summer or in London in the autumn. A colloquium on 'The early celtic world' was held in Edinburgh in September I97o to coincide with the exhibition. Miss Nancy Sandars aroused much interest on that occasion with her paper on facobsthal's enigmatic 'Orientalizing Celtic Style', and she has kindly responded to our suggestion that it should reach a wider audience here.*
\end{abstract}

When in 1944 Jacobsthal laid foundations for the study of early celtic art, foundations so enduring and so comprehensive that they still extend far beyond the flimsy structures that have shot up since, he invented an 'Orientalizing Celtic Style' as a tardy and barbaric counterpart to 'Greek orientalizing'. Having invented it, he left it, real but largly unexplained; and there it still is, very real and still in need of explanation (Jacobsthal, 1944, 156). The difficulty was, and is, that although the Celts had in their hands 'painted Greek vases and good bronze figurework ... they did not decide for Greek humanity, for gay and friendly imagery; instead they chose the weird magical symbols of the East'; yet there are no oriental goods on the workshop shelves in 'Latèneopolis', no vases, no drinkinghorns, no swords, no bangles. There is no single undoubted oriental object in a celtic grave of the early period. So Jacobsthal asked, and we still must ask, how, if there were no trade with the east and no imports to be copied, do we explain the impressively strong influence of the Orient on early celtic art? This question is my point of departure.

* The author is grateful to Dr T. G. E. Powell for suggestions in connexion with this article and also to Dr Roger Moorey for advice on the subject of Ahuramazda's chariot. For illustrations she has to thank Professor Emil Vogt of the Schweizerische Landesmuseum in Zürich for generous cooperation, also the Oriental Institute of the University of Chicago, the Trustees of the British Museum and the Württembergische Landesmuseum in Stuttgart. Mrs E. M. Cox made the drawings.
I propose to take the existence of an eastern influence on early celtic art as a thing accepted; only how it came about, and through what agents, need be questioned. In spite of the lack of imported oriental objects, could celtic craftsmen have seen and handled such things during the years most crucial for the emergence of the La Tène art style in the late 6th and $5^{\text {th }}$ centuries? I believe that they could, and the purpose of this short article is to try to identify the means. My concern will be almost entirely with the decades lying between 520 and $45^{\circ} \mathrm{BC}$. There are six significant factors that may be listed: first, shortly before 513 BC there was a Persian reconnaissance across the Black Sea, perhaps from Sinope. Next, about $5^{\mathrm{I}} 3$, Darius I led his expeditionary force over the Bosphorus and the Danube. Third, and following on this, there was an almost continuous persian presence in European Thrace and Macedonia from about $5^{13}$ till the end of the GrecoPersian wars in 479 , with an aftermath that lasted down till $45^{\circ}$. Fourth, there are certain peculiarities of the Persian imperial army and of garrisons and garrison commanders. Fifth is the building of Persepolis in these same decades, and the planning of the royal cemetery at Naqsh i Rustam nearby; and sixth, the corresponding dates of the earlier of the Altai barrow-graves, of a large part of the Oxus Treasure, and of the burial of a noble Thracian in a huge barrow near Plovdiv in Bulgaria.

Very little is known about the Black Sea reconnaissance ahead of Darius's expedition; of 


\section{ANTIQUITY}

the expedition itself more is recorded but much of it is improbable (Burn, 1962, 128; Herodotus, Iv, 83). It could never have reached the Ukraine in the time given, and was in fact a failure. It would have had little lasting importance but for the Persians who stayed behind, and the enlarged persian knowledge of eastern Europe and its inhabitants that followed from it. There was a real persianization of coastal Thrace, and permanent garrisons were put into cities on the Struma, the Maritsa, and at other strategic points. This persian presence was able to withstand at least one serious revolt, and in 486 the imperial frontier marched with Thessaly on Mt Olympos.

The young persian general left in command in Europe by Darius was Mardonios, his own son-in-law, therefore the brother-in-law of Xerxes who succeeded as Great King in 486 . The choice shows the importance of this frontier command. When even garrison commanders had with them their harems and much treasure the Commander-in-Chief lived in semi-royal splendour. The coastal Thracians sided sometimes with Greeks, sometimes with Persians, but the daughter of the King of Macedon married a persian officer, relations were established with other local notables, and the up-country mountain tribes were almost invariably hostile to the Greeks (Burn, I962, 22I ; Herodotus, vi, 45). There are interesting hints that about the time of the Greco-Persian war there was a fairly good understanding between Greeks and scythian or part-scythian tribes further north-east, but that Thracians sided with the Persians against the Greeks. We hear of fighting between Greeks and Thracians in 497, and Thucydides says that after the departure of Xerxes in 480 , when the Greeks laid siege to Eion, an important fortress on the Struma crossing, they had to cut the persian garrison off from the Thracians on the land side because they were their allies. When the city at last fell, the persian governor Boges threw broadcast into the river his enormous treasure of gold and silver, before committing suicide (Thucydides, I, 98; Herodotus, vII, I07). This was a full generation after Darius's expedition; while Doriskos, on the coast west of the
Maritsa, was not abandoned till some years later, and only the Peace of Kallias in $45^{\circ}$ put an end to persian interest in the Balkans. This long period, 35 years of occupation and persianization, with another 30 of slighter contact, was probably of more consequence to the people of the Balkans than the war itself. Alliances with local rulers meant the giving of presents, and it is known that the customary persian manner of complimenting a prince, ally or ambassador, was the gift of a horse with a gold bit, gold necklets and armlets, a gold sword (probably the sheath only was gold) and a persian robe (Xenophon, I, 2).

In the summer of 480 when Xerxes crossed the Hellespont meaning to subdue all Greece, he was joined by Thracian infantry. Herodotus gives 300,000 , which is too much, but though less than this the number was still very considerable. When they were dismissed in the autumn they are not likely to have returned home empty-handed. The muster list of the persian army reviewed by Xerxes after crossing into Europe is probably based on an authentic tax-list of persian satrapies of the early years of Darius I, and may have come from Hekataios, or Scylax of Caryanda. There are several such lists on persian monuments at Susa, Persepolis, Behistun and elsewhere; in them the empire's growth is reflected. After naming each contingent Herodotus describes their clothes and weapons, and at Persepolis we can see their carved counterpart in the delegations of the nations bringing presents. Darius I had begun building Persepolis before 504 but the work was not finished till some years later. The carved friezes on the walls and stairways of different buildings show state and religious subjects. Among the former are several portraying the people over whom the Great King ruled, or who were bound to him as close allies. The procession on the terrace and staircase of the Apadana, completed by Xerxes, probably celebrates the New Year Festival when all sorts of gifts were brought. The bracelets, necklets and vases are not peculiar to the people carrying them but belong to the current 'empire style'. They can be matched by actual finds from Thrace to Afghanistan. The clothes and 


\section{EARLY CELTIC ART}

weapons are more distinctive, as are the animals. At least three breeds of horse are shown from large roman-nosed animals of the royal stable (about 14 hands) to tiny Syrian ponies harnessed to little carts.

At Naqsh i Rustam a few kilometres away, where the royal tombs were cut out of the cliff-face, there are more friezes, and some of the representatives of the peoples are named, which they are not on the Apadana (Schmidt, 1953-7; Walser, 1966). Here we have the first naming of the Skudra or Thracians in an inscription of Darius I, as well as the Saka or Scythians 'from over the sea' indicating a date after Darius's European venture. They are shown among the supporters of the king's funeral couch. The Persians did not use tribal names but identified the delegations by where they came from, or by some oddity of dress or manners. So there are 'Saka with Pointed Caps' from the Bactrian borders, 'Saka from Over the Sea' (probably the Black Sea) and 'Hemp-addicted Saka'. The name Skudra includes Macedonians and perhaps others; they are dressed differently at Naqsh i Rustam, at Persepolis on the Apadana frieze, and again as supporters of the King's throne. Some look more asiatic, some more greek. At Naqsh i Rustam they wear cavalry trousers, but in the Apadana procession, where they are taken to be no. 19 between the Greeks and the Black Sea Saka, they lead a stallion of around Io hands, and wear calf-length boots instead of trousers. They are indeed the only horsemen not trousered. Herodotus says the Thracians wore faunskin boots, and caps of fox's skin, and bright-coloured cloaks. The relief also shows their wicker shields and long spears (PL. XXIa). The Skudra on the small throne wear fibulae and carry the 'Median' dagger or short sword, the akinakes. But it is not only the Thracians at whom we should look on the Persepolis reliefs.

The imperial Achaemenian army that garrisoned Thracian towns, and that crossed the Hellespont with Xerxes in 480 , was multiracial. Xerxes brought men from Bactria, Sogdiana, India, Egypt, even Ethiopia, all wearing their peculiar dress, using their native weapons, riding and driving their own breeds of horse, ass and camel. The persian army was in this not unlike the imperial roman army. Both brought together contingents that would normally never have set eyes on each other. Just as under Rome, Dacians, Syrians and Asturians served on Hadrian's Wall; so wild men from across the Oxus camped beside the Struma among Macedonians and Thracians of the coast and the hinterland.

The great treasure with which the army travelled was notorious. Most of it fell into Greek hands, but the spoil of the northern garrison towns went to the natives of Thrace, like that 'Chariot of Zeus', as Herodotus calls it, which was left behind on the Struma when the army marched south. When they returned in the autumn it was gone. The excuse given by the native Paeonians was that they had sent the horses to pasture in the north, and that Thracians from near the source of the Struma, not far from where Sofia now stands, had stolen them. (Herodotus, VII, 55; viII, II5). This was probably the chariot of Ahuramazda, drawn by white horses, beside which the charioteer used to walk on foot, for it was too holy to be mounted even by the Great King himself. A frieze at Persepolis shows the King's chariot, and that of the god would probably have been like it, but even more ornate (PL. $\mathrm{xxI} b$ ). The tiny gold model in the British Museum Oxus Treasure may represent just such a sacred cart. It has two occupants, but whether gods or mortals cannot be told, though the head on the front panel looks unmistakably god-like (PL. XxII $b$ ). This bearded type is sometimes named after the Egyptian 'Bes', but it is more likely to be the same as the bearded person who often appears on Luristan bronzes (FIG. $3 a$ ). Even if the Thracian robbers were more interested in the horses than the cart they would have found a use for its gold and other ornaments.

If we want to know what the weapons, jewels and table-ware that the Persians left behind in Europe looked like, we can get a very good idea from these Persepolis reliefs supplemented by the Oxus Treasure, which has been called 'the most important collection surviving of Achaemenian "Empire Style" jewellery (Dalton, r964; Barnett, 1968). It may be the loot from 


\section{ANTIQUITY}

some temple treasury on the upper Oxus which, to judge by the latest objects, was not hidden till after $170 \mathrm{BC}$. Most of it is dated on stylistic grounds in the later $5^{\text {th }}$ and $4^{\text {th }}$ centuries, but a gold sheath for an akinakes is probably preAchaemenian and its earliest object. Dr Barnett has shown that the akinakes was in the first place a Median weapon, and that this particular akinakes, ornamented in a characteristically 'median' style, probably shows Astyages, the Median king, overthrown by Cyrus and imprisoned in 549. The king on the repoussée decoration of the sheath wears an Assyrian crown and Median trousers which supports the identification (Barnett, 1962 and 1968). Persian generals very probably wore scabbards like this for the European command (PL. xxIr $a$ ).

Compared with the peoples of the persian empire the Scyths of Europe and their neighbours in central Asia and Mongolia are far more illusive. The name 'Saka' was used by Indians and Persians for the steppe people between the borders of China and the Danube. The Greeks called some of these Saka, Scyths; and some of their Scyths were freely mixed with Thracians, Dacians and Getae, so that to define and localize 'Scyths' at any time is a hard problem. What is generally meant, and it is a very loose definition, is groups of nomadic and seminomadic people who buried instead of cremating their dead, who sometimes buried horses and a whole retinue with them, and who possessed a decorative style of art of great beauty which was applied to all sorts of useful objects including their own (tattooed) bodies.

Thracians and Getae usually cremated their dead, often raising a barrow. In Herodotus's account of the Balkans at the end of the 6th century (perhaps in part derived from Hekataios) there were Scythians north of the Danube and Getae south of it. But near Histria, just south of the Danube, a cemetery of cremations under barrows has been excavated, along with large numbers of unburnt bodies of persons slaughtered kneeling, as well as muddled-up remains of horses (Alexandrescu, 1959). This is typical of the confusion of customs and populations. Romanian archaeologists do not, on the whole, accept the presence in their country of 'pure' Scyths, but prefer to account for all the so-called 'scythian' traits as due to cultural contacts, whatever that hardworked phrase may mean. But in Hungary there certainly were groups answering to the definition just given, if we take Szentes-Vekerzug. with its horses and 'scythian' art, as one example (Párducz, 1952; 1965a,b), always remembering that 'Scyth', like 'Saka', is not a tribal name. In a famous passage Herodotus refers to charioteering Sigynnae who lived close to the eastern alps. They were in contact with the Eneti or Veneti, so not all of them were north of the Danube; their territory perhaps included Sopron and Magdalenska Gora. Harmatta takes them for Scyths, but this is far from proven. They dressed 'like the Medes' according to Herodotus, which no doubt means that they wore trousers. It would be interesting to know whether Herodotus distinguished between the baggy trousers of the Saka and the tight trousers of the Medes proper (Herodotus, v, 9; Harmatta, 1968).

The 6 th century saw a dual advance round the Black Sea; Scyths moving west by land at the same time that Greeks were exploring the coasts and establishing colonies. It was not unlike the simultaneous colonization of South Africa by Bantu and European peoples, except that there was no comparable extinction of the native population. At the same time other Saka were probably exploring eastwards into central Asia, where they gave the native population a ruling class (Jettmar, I 966). They would seem to have been more successful in that direction, for there are no Pazyryks in Central Europe. Both lots of Scyths or Saka already owned objects made in the rich workshops of the Middle East.

Jacobsthal wrote that 'the beasts and masks are what give the La Tène early style its "stamp", far more than the ornaments from the south, they retain their bodies but change their souls'. We can never hope to understand those souls but let us look at a few of the bodies. Some of the earliest, if not the most successful, are the gold horn-mounts with ram's heads from Klein Aspergle, Württemberg. Drinking horns come from the east, though Greek 

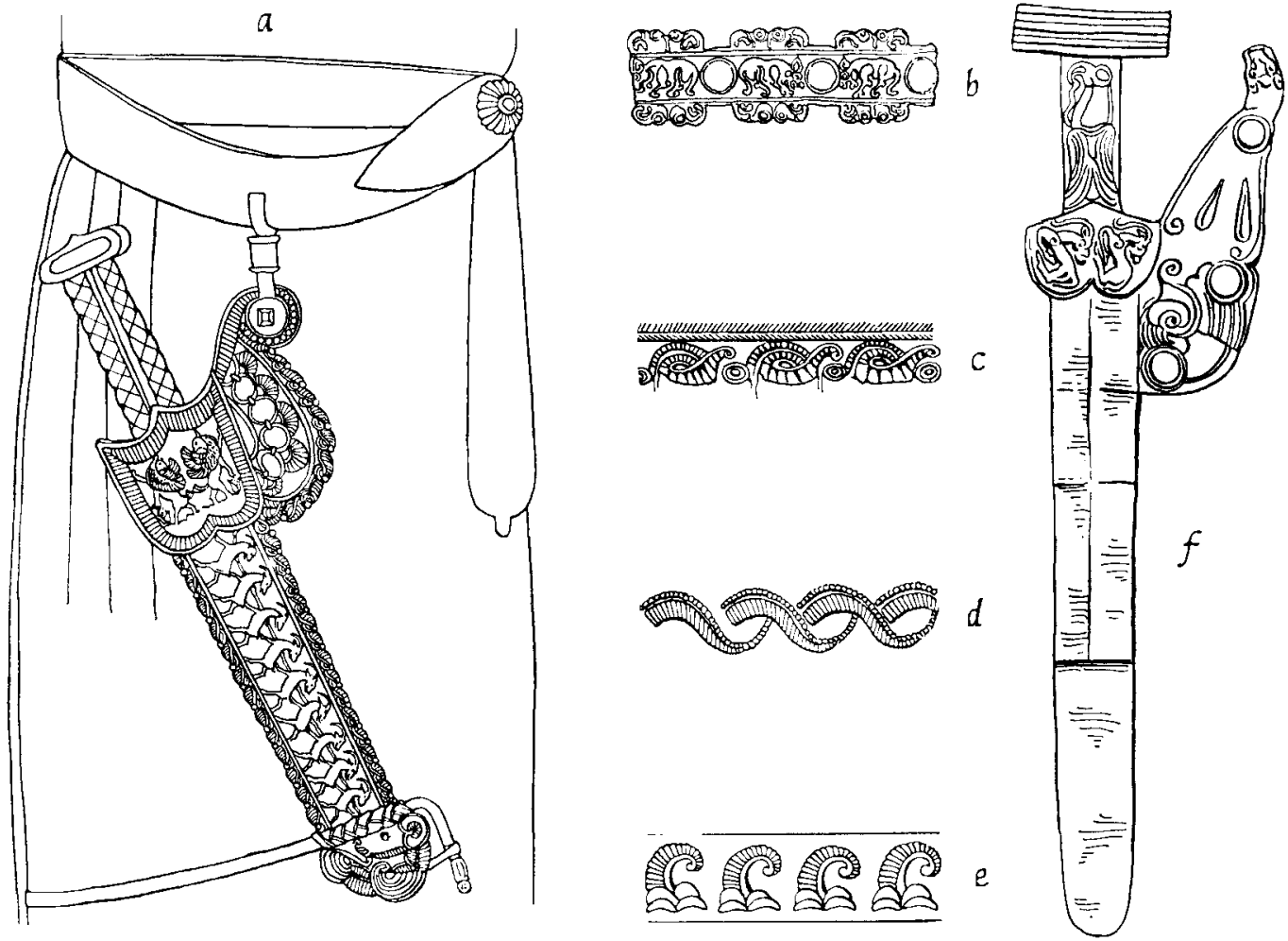

Fig. I. Swords (akinakes) and motifs: (a) Persepolis Treasury frieze; (b) Ziwiyeh gold strip; (c) Oxus Treasure gold sheath; (d) Klein Aspergle horn-mount; (e) Amfreville helmet; $(f)$ Medgidia bronze swordemblem; (after Frankfort, Godard, Dalton, Facobsthal and Berciu). Various scales

craftsmen did sometimes produce them for the barbarian market. These are based on a drinking horn with a ram's head such as was found in the fourth barrow of the Seven Brothers group north of the Caucasus (greck work from an iranian model), and buried about 470 . The scale pattern on one Klein Aspergle horn is not hard to match but we must look further afield for the tapered guilloche of the other (PL. XXIII $a$, FIG. I $d$ ). I believe that its source may be a band of connected beak-heads used as a border on the Median akinakes. It is on the gold sheath of the Oxus Treasure, and on the Persepolis reliefs, where it is worn by a court dignitary in median dress (PL. XXII $a$, FIG.I $a, c$ ). Behind this again, as Dr Barnett has shown, are the beaks edging a gold strip in the Ziwiyeh treasure buried around 600 . This treasure, found in north-west Iran, has objects of very mixed styles but chiefly 'Mannaean', that is to say derived from Urartu and Assyria with a dash of the steppe (Godard I950; Barnett, I962); a variant of the motif appears later on the fine Amfreville helmet (FIG. I $b, e$ ); while the astonishing tiara from Cucuteni-Băiceni is covered with the motif (140 in the Catalogue of the exhibition of 'Treasures from Romania at the British Museum').

Like drinking-horns, jugs with handles formed of an animal's body are oriental; they were never popular south of Macedonia, and it was again the Celts, not the Greeks, who exploited this oriental fashion. In the Apadana procession fine animal amphorae are carried by Armenians and Syrians (or Lydians; Walser, 1966, pls. 6, го, 38, 39, 46-9; Barnett, I957). 


\section{ANTIQUITY}

Exact counterparts come from Kabul and Bulgaria. In the huge tumulus of Kukuva Mogila, Duvanlij, near Plovdiv in an early 5th-century burial a silver (once gilt) amphora was found the handles of which have the form of a unique monster with a lion's head, ibex
The Dürrnberg flagon (apparently one of a pair) may have got its fluting from the east as well as the handle animal; this is one of those peculiar celtic lions with curly horns. Shoulders have always been important in oriental art; Assyrians, Persians, and Scyths used particular

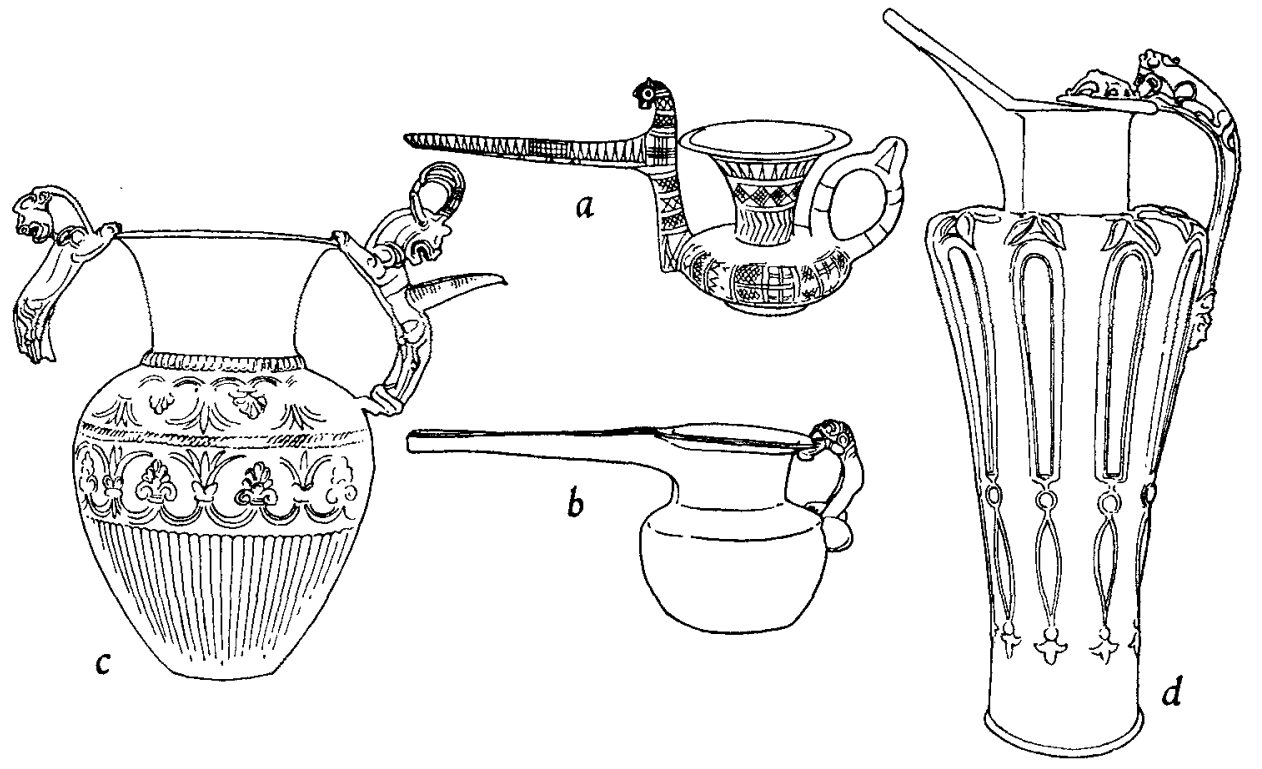

Fig. 2. Fugs and flagons: (a) Tepe Sialk, cemetery B clay; (b) 'Luristan' bronze; (c) Kukuva Mogila silver; (d) Dïrnberg bronze (after Filow, Iran Exhibition, Sandars). Various scales

horns and ears, and a bird's tail. One handle is hollow and forms the spout; only the neck, head and forelegs are three-dimensional, the rest is an ornamented rod. A painted jug from Tepe Sialk, cemetery B, and a bronze one from 'Luristan' show how handle and spout evolved (FIG. 2a-c; Filow, 1934; Amandry, 1959; Iran Exhibition, 1961-2, pl. 32, no. 372). The Duvanlij flagon is absolutely typical of the unlocalized Achaemenian court style; it probably would have come up the Maritsa when the Persians were occupying Doriscus. There was a centre of production in Armenia, but this flourished somewhat later. The celtic beaked flagons are a marriage of these oriental vases and the etruscan flagon with one handle; how and where they met we do not know, but it must have been north of the Alps. motifs to emphazise the joints, and all three Dürnberg animals have the same 'leg of mutton' shoulder. This was used on Assyrian ivories and on a silver chamfrain in the Ziwiyeh treasure (FIGS. 2d, $3^{b-c}$, Godard, 1950). It is worth noting that the large Dürnberg animal does not eat the human head but rests its chin on it, a benevolent attitude also known in Luristan. Animals with curly horns appear on several La Tène brooches, Parsberg, Oberwittighausen, and in fine goldsmith's work on the Rodenbach bracelet, and above all on that very oriental object the Weisskirchen bronze belt-clasp (Jacobsthal, 1944, pls. I 58-9, 47, 167). Curly horns have a much longer history in western Asia where they are usually worn by lions or lion-griffins, and this is why I call the Duirrnberg animals, lions. In the Altai they are 

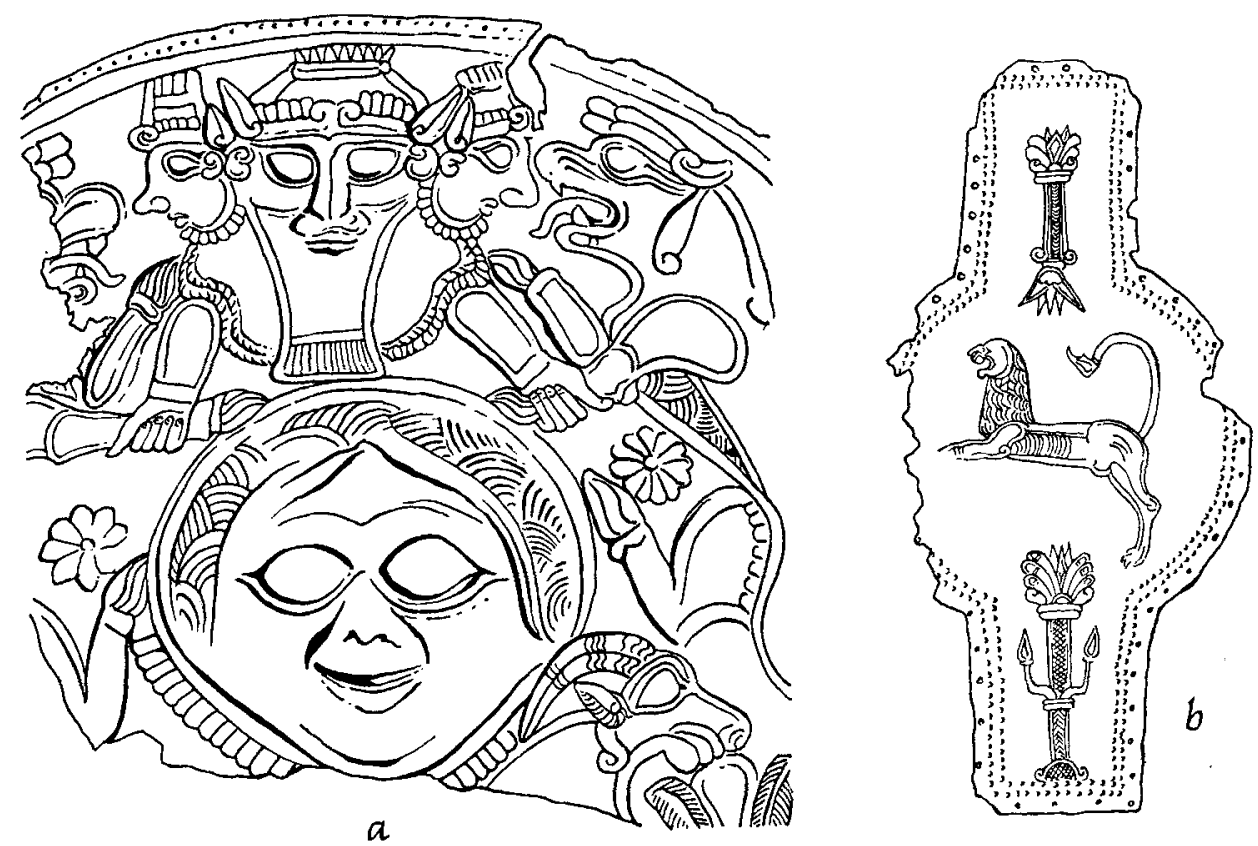

Fig. 3. Ears and joints: (a) Luristan bronze pin; (b) Ziwiyeh silver chamfrain; (c) Dïrrnberg flagon handle (after Ghirshman, Godard and Facobsthal). Various scales

confined to the second Pazyryk barrow (Rudenko, 1958, Sandars, 1968, 235). The sitting, backward-looking stance of the Weisskirchen man-monsters is also oriental; there are backward-looking peacable pairs among the Ordos bronzes, but not from the steppe regions between, though they flourish south of the Caucasus. The Weisskirchen monsters have boots with turned up toes, an Anatolian fashion which was also adopted by the Etruscans. The contorted bodies of the animals on the Dürkheim tracery are horned and Eurasian not Iranian.

Among the most oriental objects from the west are four gold torcs in the small treasure from Erstfeld, Canton Uri, Switzerland (Vogt,

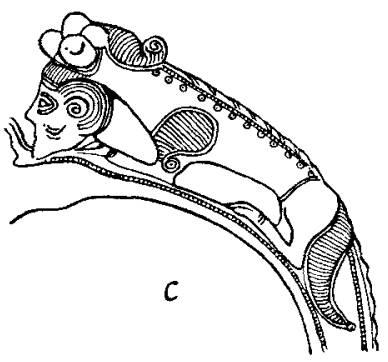

I963; Lapaire, 1969, pl. I4). Two bracelets are typical early La Tène work, but the four neck-rings with their welter of intertwining bodies are as weird as they are unexpected. The detail illustrated (PL. XXIII $b$ ) gives almost the whole ornamented portion of two of the necklets; that on the right is more sophisticated, more metropolitan, more Achaemenian, than the other. The animal, a calf or ibex, is winged but hornless and has the customary oriental neck-frill or collar. The other detail shows an animal and a human figure sharing one body and wearing a sort of kilt with a chequer pattern like figures on Ziwiyeh ivories (Godard, 1950). On another necklet (Vogt, 1963, fig. 8) the more human of the figures grips the neck and leg of 


\section{ANTIQUITY}

a bird. Just such gripping, biting little creatures swarm over Luristan bronzes. The damaged pin from 'Luristan' (FIG. $3 a$ ) shows a mythological scene that Professor Ghirshman has interpreted as the bearded Zurvan, endless time or destiny, between the twins of light and darkness, Ahuramazda and Ahriman (Ghirshman, 1958). However that may be, the bearded individual is iconographically allied to the head on the Oxus cart (PL. XXu $b$ ), while the twin-figures grip the lion's leg with the same gesture as those on the Erstfeld torc. These Luristan bronzes are notoriously difficult to date but seem to lie between $1000 \mathrm{BC}$ and the start of the Achaemenian period. We shall probably never know what the Erstfeld torcs were doing on this northsouth alpine route: they owe nothing to the Etruscans, but parallel transformations of Achaemenian and Elamite art took place as far east as the borders of China.

The two flagons from Basse Yutz, Lorraine, were made in the fourth century some time after the formative period of $\mathrm{La}$ Tène art (Jacobsthal, 1944, 39; Sandars, 1968, 236). The animals of the handle and rim belong to central Asia, for although oriental felines lurk in their remoter ancestry, these are no lions: they are wolves or wolf-hounds. The wolf was the especial terror of the northern forest where it was often carved in wood and bone. These animals have spiral ear and joint motifs that were more popular with the Scyths of central Asia than with their relatives further west. The barrows of Pazyryk, Bashadur, Tuekti and Katanda, all in the Altai, are full of them. Some may be as early as $520 \mathrm{BC}$, but the Pazyryk animals, including a crouching lion and another with a rod-like body, are of much the same date as the flagons (FIG. $4 a-d$; Rudenko, I953; Jettmar, 1967, 135). Spiral ears and joints are infrequent in La Tène work; the little horned felines of the Parsberg brooch have them and are closest in style to the Basse Yutz animals; we also see them on the Dürkheim tracery already referred to. It is not however quite true that otherwise they belong entirely to Siberia and China, as Jacobsthal says (1944, $3^{8}$ ). The persons, human and animal of the Luristan pin (FIG. $3 a$ ) have them, so do the stags and
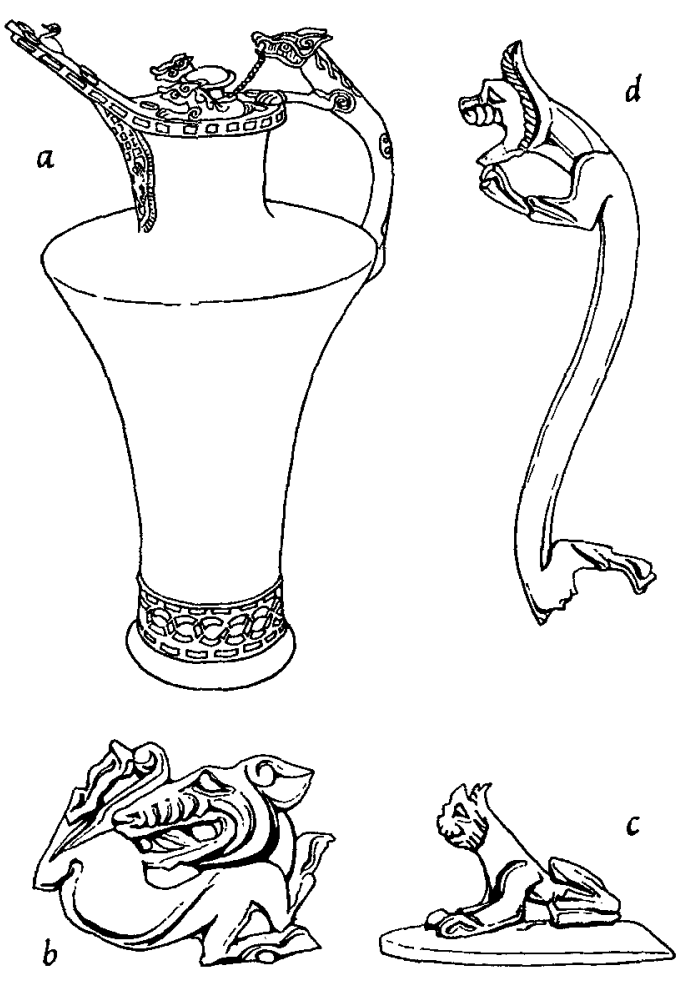

Fig. 4. The eurasiatic alternative: (a) Basse Yutz bronze flagon (the animals); (b-c) Pazyryk third barrow, wood partly covered with metal foil; $(d)$ Pazyryk fourth barrow wood (after Facobsthal and Rudenko). Various scales

lions on a silver flask from $\mathrm{Kul} \mathrm{Oba,} \mathrm{which} \mathrm{is}$ Greek work for the eastern market (Minns, I9I3, fig. 9r). They were also used by the western Scyths on the shoulders of two animals on an iron sword from Dobolii de Jos (Minns, 1913, Aldoboly, fig. 18) and on the backwardlooking ibexes of the bronze emblem in the form of an akinakes from Medgidia in the Dobrogea, which may be $5^{\text {th }}$ century (FIG. If; Berciu, 1958). The beaky birds of the hilt are in the tradition of the steppe west of the Urals, while the full-face feline recalls that on the gold pectoral from Duvanlij (Filow, 1934, pl. II, r). This is very far from the world of Persian governors and imperial armies, it is the 'alternative art' which, like the other, was absorbed and transformed in celtic workshops by the creators of the Basse Yutz flagons, or the 


\section{EARLY CELTIC ART}

Brno Maloměrice bronze openwork mount. This is another eclectic object, for the animal head on the larger fitting, which I take to be an ibex, has the curved horns and furrowed eyebrows of an Achaemenian animal head, while the sharp angle between planes is Scythian (Sandars, 1968, 241). The list of oriental borrowings could be enormously expanded from the 'Astarte at the window' from Dürkheim (Jacobsthal, r944, pl. 25, no. 28) to the Trichtingen and Vieille-Toulouse torcs, and tip-toe boars that go back to Urartu (see also Mariën, I960, 265).

With Scyths on the Hungarian plain, and with the products of Achaemenian gold and silversmiths on the upper Maritsa and at the source of the Struma, we are some way towards answering those questions concerning date and place of origin of the eastern component in early celtic art with which we began. It is not a case of bridging vast spaces between the Urals and Bavaria, or between the Euphrates and the upper Danube. Certain motifs no doubt had their own particular range in the Eurasiatic zone (Rudenko, I958; Jettmar, I966) and we know virtually nothing about the organization of Scythian workshops, nor how they served their clients, and little more of the Achaemenian.

Herodotus knew that the Danube was navigable and that it rose in celtic country, and Herodotus had travelled much in Persian lands; what he recorded was almost certainly common knowledge in the Aegean and western Asia. But it is still a long way to $5^{\text {th-century celtic }}$ workshops in central Europe. It is no good looking for the sort of documentation provided by Greek historians and colonists; the evidence, if any, will be oblique. It is worth remembering that interesting list of persian state presents: the robes, the necklets, armlets, swords and bits.

At the same time that Achaemenian and Scythian influences were giving rise to a 'celtic orientalizing art' in central Europe, other influences, stemming from the same oriental sources, but travelling through different intermediaries and by different routes, gave rise to another metallurgical school in Romania and the Balkans. It produced work of some magnificence, but it never achieved the synthesis and harmony of 'celtic orientalizing'. Its most famous objects are the gold and silver tiaras of Poiana Coţofeneşti and Hagighiol, along with beakers from Romanian sites and plaques in the Bulgarian Letnica and other treasures, with certain phalerae scattered between Taman and the Channel Isles. There is the same background of iranian (Marlik), mannaean and median art, but the native recipients were quite different; their contribution was weaker and they never achieved the synthesis of La Tène art. It remained an undigested, sometimes uncouth style; but it was this that some time later produced the panels of the Gundestrup cauldron, hardly celtic, certainly not La Tène: a no less fascinating, but a different story (Powell, r97I).

To measure the achievement of the orientalizing La Tène artists we need only compare their synthesis with such monstrosities as the Panagurishte treasure, or even the silver vase from Chertomlyk, Greek work of the $4^{\text {th }}$ century produced to flatter the natives up the Dniepre. The impact of late Greek art on the people of Russia and in Central Europe was totally different. Brajčevskij has shown how the former, because of the enormous competence and total lack of understanding, had no effect whatsoever on local arts, but may actually have retarded the development of a native style. The finest nomad art comes from beyond the Greek orbit, from the Urals and the Altai (Brajčevskij, I965). The greek work was too alien and too mature and there was no reciprocity. In central Europe on the other hand, though Greek work was known and admired, there was no flooding of the native market, and native craftsmen were able, without any sense of inferiority, to adapt and reject and transform as they pleased, and so to keep their own artistic integrity. Not till Rome began to flood this particular area were the native arts degraded, and for the same reasons. Until that time celtic craftsmanship held these diverse elements fused and in equilibrium, and when, after the centuries of roman dominance, it reemerged in the decoration of manuscripts and in metal-work, the orientalizing element, though perfectly fused, can still be sensed. 


\section{ANTIQUITY}

\section{BIBLIOGRAPHY}

ALEXANDRESCU, P. and v. EFTIMIE. I959. Tombes thraces d'époque archaïque dans la nécropole tumulaire d'Histria, Dacia, N.S. III, I43-64.

AMandry, P. 1959. Toreutique Achéménide, Antike Kunst, 11, 38-56.

BARNETT, R. I956. The treasure of Ziwiye, Iraq, XVIII, I I I-I6.

1957. Persepolis, Iraq, xIx, 55-77.

1962. Median art, Iranica Antiqua, II, 77-95.

1968. The art of Bactria and the treasure of the Oxus, Iranica Antiqua, viII, 34-53.

BERCIU, D. I958. Thraco-Scythian sword-emblem from Medgidia, Dacia, N.S. 11, 93-124.

BRAJČEVSKIJ, M. 1965. Influence culturelle de la pontide antique, Congrès International d'Archéologie Slav, II, Warsaw, 372-8.

BURN, A. R. 1962. Persia and the Greeks c.546-478. (London).

DALTON, o. I964. The Treasure of the Oxus, $3 \mathrm{rd}$. ed. (London).

FILow, в. 1934. Die Grabhügelnekropole bei Duvanlij in Südbulgarien (Sofia).

FRANKFORT, H. 1954. The art and architecture of the Ancient Orient (Harmondsworth).

GHIRSHMAN, R. 1958. Le dieu Zurvan sur les bronzes de Luristan, Artibus Asiae, xxxI, 37-42.

1964. Persia from the origins to Alexander the Great (London).

GODARD, A. 1950. Le Trésor de Zizwiyè (Haarlem).

harmatta, J. 1968. Früheisenzeitliche Beziehungen zwischen dem Karpatenbecken, Oberitalien und Griechenland, Acta Archaeologica Academiae Scientiarum Hungaricae, xx, I 53-7.

HERODOTUS. Histories.

IRAN EXHIBITION. I96I-2. 7000 ans d'art en Iran, Catalogue (Paris).

JACOBSThal, P. 1944. Early celtic art (Oxford).

JETTMAR, K. 1966. Mittelasiatische Bestattungsrituale und Tierstil, Iranica Antiqua, vi, 6-24.

1967 (1964). Art of the Steppes (London).

LAPAIRE, C. I969. Das Schweizerische Landesmuseum in Zürich, Hauptstücke aus seinem Sammlungen (Zurich).
MARIËN, M. I960. Masques celtiques et bronzes Luristanais, in (ed.), H. Reykers, Analecta Archaeologica (Festschrift für F. Fremensdorf), $265-7$.

MINNS, E. 1913. Scythians and Greeks (Cambridge).

PÁRDUCZ, M. 1952. Le cimitière hallstattien de Szentes-Vekerzug, Acta Archaeologica Academiae Scientiarum Hungaricae, II, I43-83.

1954. Le cimitière hallstattien de Szentes-Vekerzug II, Acta Archaeologica Academiae Scientiarum Hungaricae, Iv, 25-91.

1965a. Graves from the Scythian age in Artánd, Acta Archaeologica Academiae Scientiarum Hungaricae, xvII, I37-23I.

I $965 \mathrm{~b}$. Western relations of the Scythian age culture of the Great Hungarian Plain, Acta Antiqua Academiae Scientiarum Hungaricae, xIII, 273-301.

POWELL, T. G. E. I97I. From Urartu to Gundestrup: the agency of Thracian metalwork, in (ed.), J. Boardman, M. A. Brown and T. G. E. Powell, The European community in later prehistory (London) 181-210.

ROSTOVTSEFF, M. I922. Iranians and Greeks in South Russia (Oxford).

RUDENKo, s. 1953. Kultura Naseleniya Gornogo Altaya v Skifskoe Vremya (Moscow).

1958. The mythological eagle, the gryphon, the winged lion and the wolf in the art of the northern nomads, Artibus Asiae, xxxi, ror-22.

SANDARs, N. K. I968. Prehistoric art in Europe (Harmondsworth).

SCHMIDT, E. F, 1953-7. Persepolis, University of Chicago Oriental Institute Publications, vol. LxviII (Chicago).

THUCYDIDEs. The Peloponnesian War.

voGT, E. I 963. The Celtic gold treasure of Erstfeld in Switzerland, Illustrated London News, I 2 January, 48-49.

WALSER, G. r966. Volkerschaften auf Reliefs von Persepolis, (Berlin).

XENOPHON. Anabasis. 

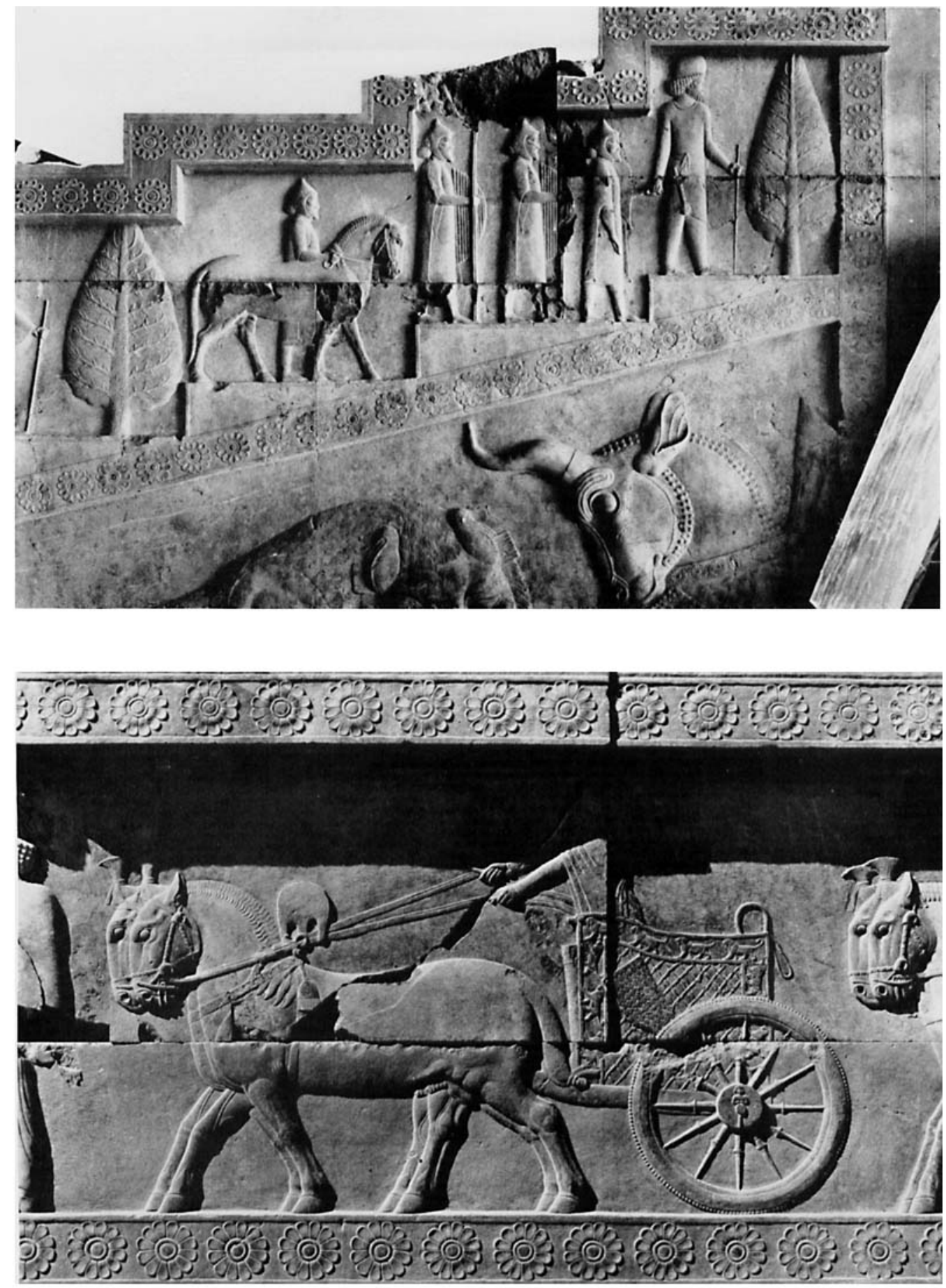

PLATE XXI: ORIENT AND ORIENTALIZING IN EARLY CELTIC ART

Persepolis the Apadana: (a) figures on left side of eastern stairway, 'Skudri'. Ht of figures: c. 56-60 cm.; (b) eastern stairway, the chariot of Xerxes. Diameter of wheel c. $0.40 \mathrm{~m}$. 

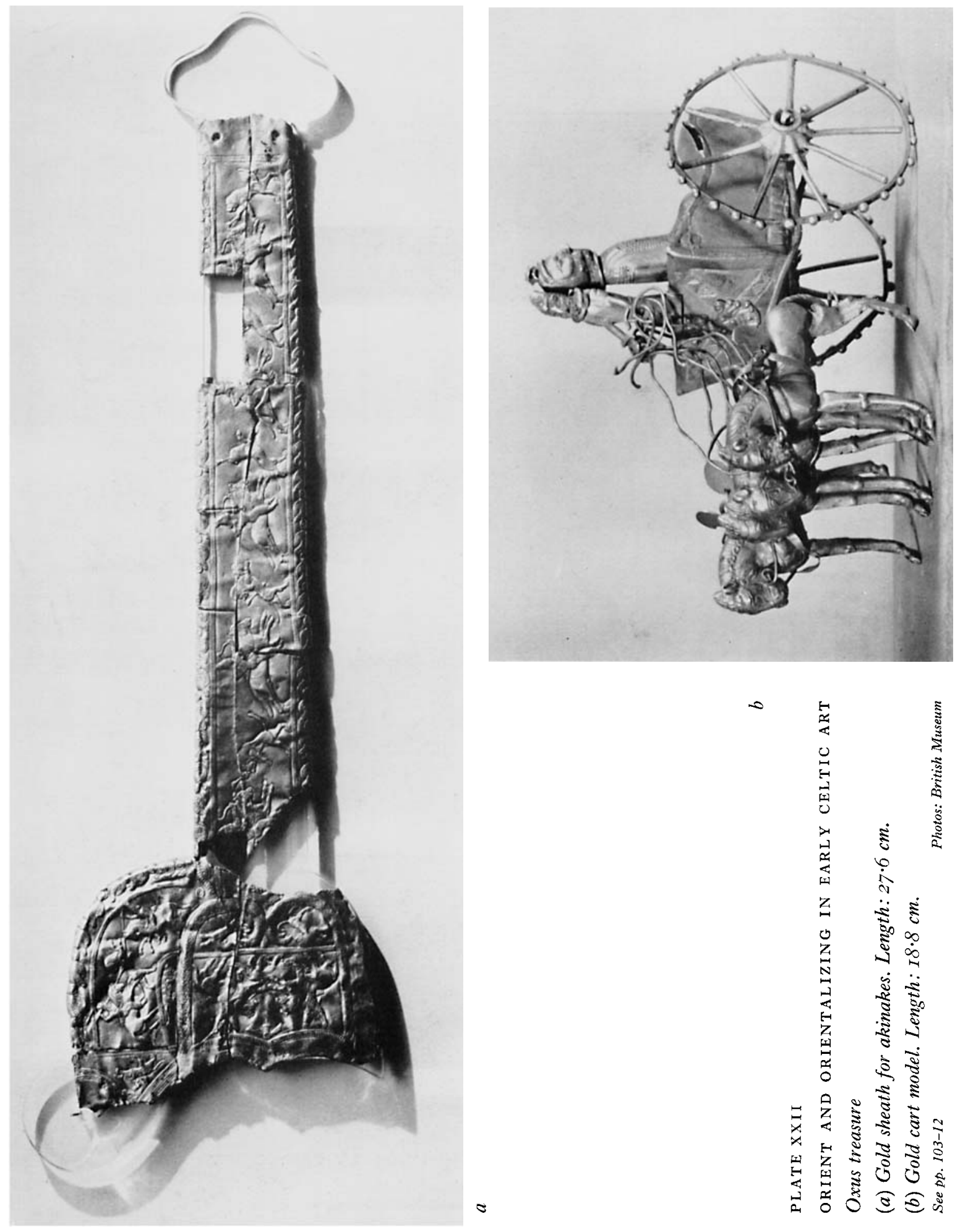

$\sigma$

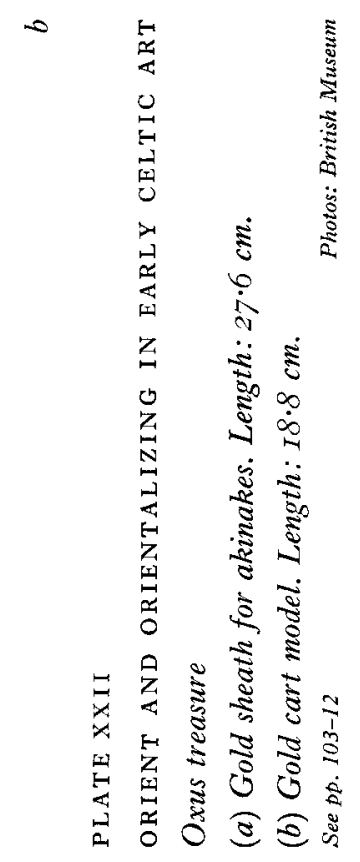



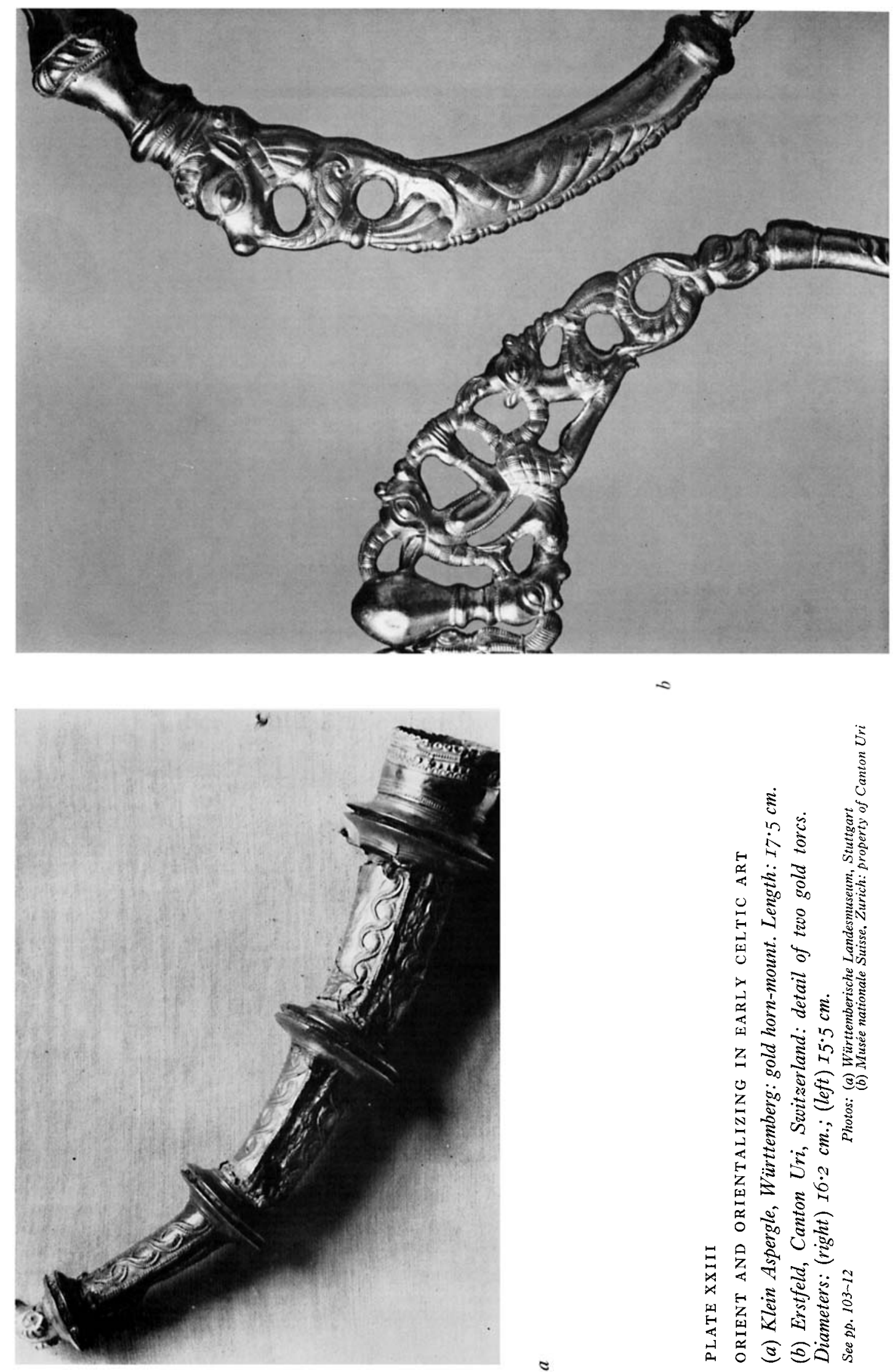